\title{
МЕТОДИЧНЕ ЗАБЕЗПЕЧЕННЯ ДОСЛІДЖЕННЯ СПОРТИВНИХ КОМУНІКАЦІЙ В СУЧАСНОМУ МЕДІАПРОСТОРІ
}

\author{
Антон Карнаух \\ Класичний приватний університет \\ вул. Жуковського 70-б, 69002, Запоріжжя, Україна \\ e-mail: anton.karnauh@ukr.net \\ https://orcid.org/0000-0002-0683-9849
}

Стаття присвячена дослідженню методичного забезпечення спортивних комунікацій у сучасному медіапросторі. Автор проаналізував методи логічного та стратегічного аналізу, а також критеріальні методи, які доцільно використовувати для дослідження чинників зовнішнього середовища спортивних комунікацій.

Ключові слова: спортивні комунікації, фактори впливу, стратегія розвитку, загальні методи, локальні методи.

Постановка проблеми. Спортивна галузь - це стратегічно важливий комплекс для розвитку не лише комунікацій, а й національної економіки в цілому. Саме через розвиток спортивних організацій, закладів, центрів підвищується увага до спортивних заходів та збільшується попит на заняття масовим та професійним спортом. Таким чином можна значно поліпшити рівень добробуту громадян у країні та створити підгрунтя для стабільного функціонування всіх систем на державному рівні.

Аналіз останніх досліджень з проблематики роботи. Теоретичні та практичні аспекти методичного забезпечення спортивних комунікацій в сучасному медіапросторі України досліджені фрагментарно, не у всіх аспектах. Певні напрацювання є у М. Житарюка, В. Житарюк, В. Іванченка, О. Корольової, А. Сови, В. Тарасюка та ін. Беручи до уваги постійні зміни в зовнішньому середовищі, які впливають на розвиток спортивних комунікацій, необхідно ретельно досліджувати тенденції, характерні риси, які формують галузь спорту та сферу ЗМІ й методологію їх дослідження в сучасному медіапросторі.

Метою статті є визначення методології дослідження спортивних комунікацій в сучасному медіапросторі.

Завдання нашого дослідження:

- визначення методів, які дозволять комплексно схарактеризувати розвиток спортивних комунікацій в Україні;

- аналіз загальних та локальних методів.

(C) Карнаух А., 2019

Наукове керівництво, редагування і рекомендація до друку - проф. Пенчук I. Л. 
Результати дослідження. Для детального аналізу факторів зовнішнього та внутрішнього середовища спортивних комунікацій можна обрати загальні або локальні методи. Але доцільно буде дослідити чинники окремо, згрупувавши їх у категорії за певними критеріями. 3 цією метою ми можемо зосередити увагу на експертних, математичних, критеріальних, графічних та статистичних методах.

У межах свого дослідження ми вирішили застосовувати перераховані інструменти в комплексі для отримання більш повних та достовірних результатів. Отримані в ході проведення дослідження дані можна використовувати для виявлення слабких та сильних сторін спортивних комунікацій, а також для розроблення практичних рекомендацій щодо розвитку системи в цілому та її складових.

Особливу увагу в дослідженні необхідно приділити тим чинникам, які стануть основою аналізу. Оскільки ми розглядаємо фактори, які впливають на розвиток спортивних комунікацій, які слугують не лише частиною медіапростору, а й виступають складовою соціального конструювання спорту, то при аналізі доцільним буде використання експертного методу.

Аналіз дослідження чинників зовнішнього середовища спортивних комунікацій доцільно проводити з використанням як критеріальних методів, так і методів логічного та стратегічного аналізу.

Для проведення аналізу чинників зовнішнього середовища вважаємо, що необхідно взяти до уваги застосування таких інструментів як контент-аналіз, метод експертних оцінок, метод екстраполяції, критеріальний метод, SWOT та PEST-аналіз.

У загальному вигляді процес аналізу розвитку, функціонування та становлення спортивних комунікацій у ході нашого дослідження можна розглядати за такими етапами:

- обгрунтування доцільності дослідження розвитку та функціонування спортивних комунікацій як складової медіапростору та чинника соціального конструювання спорту (визначення основних складових спортивних комунікацій, розробка практичних заходів для розвитку спортивних комунікацій, аналіз шляхів використання попереднього досвіду та внутрішніх резервів);

- вибір структурних факторів та ключових чинників, які впливають на функціонування та розвиток спортивних комунікацій, а також створюють умови для застосування можливостей внутрішнього середовища спортивних комунікацій та дозволяють мінімізувати або ліквідувати негативний вплив загроз політичного, економічного, технологічного та соціального-культурного характеру;

- обгрунтування обраних чинників за критеріальними або груповими ознаками;

- обгрунтування та розробка практичних заходів та сценаріїв, які дозволять вийти спортивним комунікаціям на новий рівень розвитку.

У нашому дослідженні була застосована модель багатофакторного аналізу. У загальному вигляді багатофакторна регресійна лінійна модель має наступну форму $[1$, c. 5]:

$$
Y=a_{0}+a_{1} x_{1}+a_{2} x_{2}+\ldots+a_{p} x_{p}+e
$$

де $Y$ - розвиток спортивних комунікацій;

$x_{1}, x_{2}, \ldots, x_{p}-$ чинники, які впливають на розвиток спортивних комунікацій; 
$a_{0}, a_{1}, a_{2}, \ldots, a_{p}$ - ступінь впливу чинників, які впливають на розвиток спортивних комунікацій;

$e$ - випадкова величина (похибка).

Дослідження зазначених елементів системи в моделі багатофакторної лінійної регресії доцільно зробити за допомогою матричного аналізу. Використання алгоритмів матриці та диференційного аналізу дозволить охопити всі виявлені чинники та побачити картину в повному обсязі.

Головна мета проведення матричного аналізу - емпіричне обгрунтування впливу визначених факторів на функціонування та розвиток всієї системи, а також її окремих складових $\left(a_{0}, a_{1}, a_{2}, \ldots, a_{p}\right)$. Це можливо зробити використовуючи матричний алгоритм у межах економетричного аналізу:

$$
A=\left(X / X^{\prime}\right)-1 X / y
$$

де а - ступінь впливу конкретного чинника (представлена за допомогою вектора-стовпця);

$X$ - матриця чинників, які входять до складу когнітивної моделі;

$X^{\prime}$ - транспонована матриця до кожного X;

$X / X^{\prime}$ - обернена матриця до суми матриць $X$ та $X^{\prime}$;

$y$-вектор-стовпець, які характеризують розвиток спортивних комунікацій.

Моделі цього типу передбачають емпіричний підбір таких показників $a_{0}, a_{1}, a_{2}, \ldots, a_{p}$, за яких випадкова величина (похибка) наближена до мінімального значення. Під похибкою в межах даного дослідження ми розуміємо відхилення прогнозних показників розвитку спортивних комунікацій (результатів) від їх фактичних значень [2].

Автор вважає, що використання когнітивного моделювання буде доцільним при розробці стратегії розвитку спортивних комунікацій. Цей вибір пояснюється тим, що певні характеристики об'єкту дослідження не дозволяють застосувати математичні методи для методичного забезпечення. Наразі чинники впливу спортивних комунікацій, які ми взяли за основу для побудови когнітивної моделі, мають слабо структуровані характеристики, які відповідають головним умовам використання когнітивного підходу. До того ж саме застосування цього методу дозволить нам досягти головну мету дослідження - вирішити статичні та динамічні завдання.

Принцип застосування когнітивного методу виражається в визначенні серед можливих альтернатив раціональних та оптимальних сценаріїв розвитку об'єкту дослідження. Технологія моделювання дозволяє застосувати випереджальні кроки, які допоможуть уникнути кризових явищ та мінімізувати вплив загроз зовнішнього середовища. При умові виникнення конфліктних ситуацій застосування когнітивного підходу дозволяє прийняти таке рішення, яке буде розроблене та здійснене 3 урахуванням інтересів досліджуваної системи.

Класичне використання когнітивного підходу передбачає наявність двох складових: когнітивна модель та когнітивна структура. Когнітивна структура обіймає комплексну інформацію щодо самого об'єкту, його зовнішнє середовище та чинники впливу. Таким чином вивчаються та аналізуються структурні зв'язки між факторами внутрішнього та зовнішнього середовища функціонування об'єкту, їх влив один на одного та на систему в цілому. 
Когнітивна структура передбачає проходження наступних етапів [3]:

1. Виокремлення факторів впливу.

1.1. Визначення факторів, які є структуроутворюючими та основними, тобто мають максимальний вплив на функціонування та розвиток досліджуваного об'єкту.

1.2. Виокремлення серед визначених факторів цільових чинників в системі.

1.3. Виокремлення серед визначених факторів керуючих, зміна яких знаходить відображення на динаміці цільових чинниках.

1.4. Виокремлення серед визначених факторів чинників-індикаторів, які будуть демонструвати зміну системи в цілому при впливі на керовані чинники та пояснювати розвиток процесів досліджуваного об'єкту.

2. Групування визначених чинників за об'єднавчими критеріями. Це об'єднання дозволить продемонструвати за рахунок чого саме розвивається та функціонує система, а також які рушійні сили становлять загрозу та мають негативний вплив на досліджуваний об’єкт.

2.1. Виокремлення факторів, які демонструють позитивні та негативні тенденції розвитку та функціонування системи.

2.2. Виокремлення факторів, які мають максимальний вплив на розвиток та функціонування системи.

3. Аналіз зв'язків між факторами:

3.1. Визначення наявності взаємозалежних зв'язків між факторами та ступеню їх впливу на систему та на виокремленні групи факторів.

3.2. Визначення взаємозалежних зв'язків всередині групи факторів:

3.2.1. Визначення напрямів впливу чинників.

3.2.2. Визначення характеру впливу зв'язків факторів один на одного - позитивних чи негативних.

3.3. Визначення характеру контурів (посилюючі або стабілізуючі), які з'являються в результаті взаємодії факторів.

4. Побудова когнітивної моделі.

5. Розробка сценаріїв розвитку досліджуваного об’єкту з урахуванням впливу факторів.

Найбільшої уваги при створені когнітивної моделі заслуговують цільові фактори. Саме від їх визначення буде залежати розробка сценаріїв розвитку досліджуваного об'єкту. Цільові чинник є стратегічно важливими і повинні враховувати всі умовив функціонування системи, а також вплив кожного фактору зовнішнього та внутрішнього середовища на об'єкт.

Вважаємо, що виокремлення базових чинників доцільно зробити за допомогою проведення SWOT та PEST-аналізів. Застосування SWOT-аналізу дозволить виявити фактори впливу зовнішнього та внутрішнього середовища на стратегічний розвиток спортивних комунікацій. За допомогою проведення даної методології ми зможемо визначити ті чинники, які представляють загрозу для розвитку та функціонування системи, а також чинники, які дозволять досягти за певний проміжок часу поставлених цілей.

PEST-аналіз - це матричний метод, який дозволяє згрупувати фактори впливу на економічні, соціальні, технологічні та політичні, які формують внутрішнє та зовнішнє середовище досліджуваного об'єкту. 
Використання когнітивного підходу дозволяє розробити конкретні шляхи подолання кризових явищ, поліпшення теперішнього стану досліджуваного об’єкту та сформувати діючі сценарії розвитку. Практичне застосування когнітивного методу передбачає виконання наступних етапів [3]:

- проведення аналізу чутливості;

- побудова когнітивної моделі;

- сценарне моделювання;

- імпульсний вплив на керуючі чинники;

- проведення сценарного аналізу;

- вибір оптимальної альтернативи розвитку системи серед запропонованих сценаріїв.

Матриця прискорення та матриця гальмування - інструменти, які дозволяють провести аналіз чутливості досліджуваного об'єкту. Матриці демонструють стимулюючі та гальмуючі ознаки обраних факторів впливу. Використовуючи метод експертних оцінок кожний чинник оцінюється з точки зору впливу на інші фактори в межах дослідження. Таким чином в результаті ми отримаємо експертні оцінки характеристик прискорення та гальмування всіх факторів впливу.

Наразі виділяють такі етапи проведення аналізу чутливості [3]:

- визначення базових факторів впливу на об'єкт дослідження;

- оцінка характеру зв'язків факторів впливу на об’єкт дослідження;

- визначення характеру впливу кожного із факторів в системі (стимулюючий чи гальмуючий);

- градація кожного із факторів в матрицях гальмування та стимулювання в межах дослідження системи.

Створення матриць гальмування та стимулювання та подальша інтерпретація взаємодії факторів при проведенні аналізу чутливості дозволяє визначити ступінь та характер впливу факторів один на одного, а також на систему в цілому. Для того, щоб інтерпретація була більш зрозумілою, необхідно застосування стандартизованої шкали оцінки впливу чинників. Автор обрав наступну шкалу, яка дозволить отримати репрезентативні дані в результаті проведення аналізу чутливості та формуванні матриць стимулювання та гальмування:

2,0 - високий ступінь впливу фактору;

1,0 - середній ступінь впливу фактору;

0,5 - низький ступінь впливу фактору;

0,1 - вплив фактору незначний або його не існує.

У результаті проведення аналізу чутливості можна сформувати когнітивну модель, яка дозволить продемонструвати досліджуваний об’єкт в цілому, характер та тип зв'язків між чинниками впливу, їх взаємодію та взаємозалежність. Використання когнітивного підходу демонструє наочно взаємодію та взаємозв'язок чинників впливу внутрішнього та зовнішнього середовища об'єкту дослідження.

Після проведення аналізу чутливості переходимо до побудови когнітивної карти та імпульсного сценарного моделювання, після інтерпретації результатів якого можна переходити до розробки сценаріїв розвитку системи. Сценарне моделювання відбувається на основі проведення відповідного плану експерименту.

Висновки. Розроблення сценарного моделювання можливо за умови надання імпульсів збурення у обрані чинники. У конкретну вершину подається імпульс, 
який дозволяє побачити зміни в системі. Таким чином це дозволить нам побачити тенденції розвитку системи і те, який саме вплив чинить зміна одного фактора на всі інші, об'єкт дослідження взагалі.

Після проведення сценарного аналізу ми маємо можливість за рахунок імпульсного сценарного моделювання розробити сценарії розвитку об'єкта дослідження 3 негативною, нейтральною та позитивною тенденцією з урахуванням впливу факторів внутрішнього та зовнішнього середовища. Розроблені сценарії дозволяють обрати оптимальний за сучасних умов функціонування.

\section{REFERENCES}

1. Раєвнєва О. В. Управління розвитком підприємства: методологія, механізми, моделі : монографія. Харків : ІНЖЕК, 2006. 496 с.

2. Altman E. I. Financial Rations. Discriminent Analysis and the Prediction of Corporate Bankruptcy // Journal of Finance. 1968. September. P. 171-193.

3. Корноушенко Е. К. Когнитивные технологии для поддержки и принятия управленческих решений // Информационное общество. 1999. Вып. 2. С. 50-54.

4. Житарюк Мар'ян. Великий спорт і мас-медіа: Навчальний посібник. Львів: Світ, 1997. $84 \mathrm{c}$. 


\title{
METHODOLOGICAL SUPPORT FOR RESEARCH OF SPORTS COMMUNICATIONS IN MODERN MEDIAPROSTORY
}

\author{
Anton Karnaukh \\ Classic Private University \\ Zhukovskoho str., 70b, 69002, Zaporizhia Ukraine \\ e-mail: anton.karnauh@ukr.net \\ https://orcid.org/0000-0002-0683-9849
}

The article is devoted to the research of methodical provision of sports communications in the modern media space. The author analyzed the methods of logical and strategic analysis, as well as criterial methods that should be used to study the factors of the environment of sports communications. Within our research, we have decided to use the listed tools in a complex to get more complete and reliable results. The data obtained during the survey can be used to identify the weak and strong points of sports communications, as well as to develop practical recommendations for the development of the system as a whole and its components. Particular attention in the study should be given to those factors that will be the basis of analysis. Since the work will consider the factors that affect the development of sports communications, which serve not only part of the media space, but also serve as an integral part of the social construction of sport, then in the analysis it will be advisable to use the expert method.

Analysis of the study of the factors of the environment of sports communications should be conducted using logical and strategic analysis methods, as well as criterion methods. To analyze the factors of the environment we consider that it is necessary to take into account the use of such tools as content analysis, expert estimation method, extrapolation method, criterion method, SWOT and PEST analysis. The author believes that the use of cognitive modeling will be appropriate in developing strategies for the development of sports communications. This choice is due to the fact that certain characteristics of the object of study do not allow the use of mathematical methods for methodological support. At the moment, the factors of the influence of sports communications, which we have used as a basis for constructing a cognitive model, have poorly structured characteristics that meet the basic conditions for using the cognitive approach. In addition, the very use of this method will allow us to achieve the main goal of the study - to solve static and dynamic tasks. The principle of using the cognitive method is expressed in the definition among the possible alternatives of rational and optimal scenarios for the development of the research object.

Key words: sports communication, factors of influence, development strategy, general methods, local methods. 